\title{
Immunohistochemical Expression of P16 Protein and TGF $\beta 1$ in Mice Liver Exposed to Fumonisin B1
}

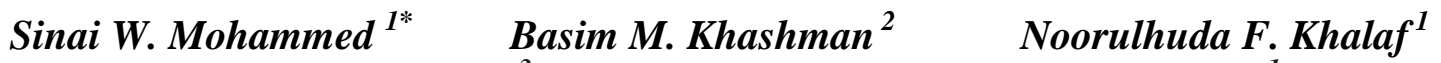 \\ Munira Ch. Ismeeal ${ }^{3} \quad$ Maysaa Kadhim Al-Malkey ${ }^{1}$
}

Received 18/1/2019, Accepted 15/10/2019, Published 1/6/2020

This work is licensed under a Creative Commons Attribution 4.0 International License.

\begin{abstract}
:
Fumonisin B1 (FB1) is a mycotoxin produced in some grains (mainly corn) by Fusarium species. Due to a structural similarity between FB1 and sphinganine, sphingolipids metabolism is inhibited. Such inhibition plays a critical role in cell to cell singling and structure of lipoprotein; therefore FB1 has been suggested to have a relationship with human and animal cancer. This research is planned to study the effect of FB1 on male mice at two doses $(20$ and $30 \mu \mathrm{g} / \mathrm{ml})$ on the expression of TGF- $\beta 1$ and p16 in liver cells. Three groups of Swiss albino male mice; each group was orally administrated with FB1 toxin as the following: normal saline (control group); 20 and $30 \mu \mathrm{g} / \mathrm{ml}$. All groups were sacrificed after two weeks of oral management. Liver samples were collected and prepared for immunohistochemistry technique (IHC) using anti-TGF- $\beta 1$ and anti-p16 antibodies. The results showed that exposure to FB1 caused significant elevation of TGF- $\beta 1$ in both doses $(76.74 \pm 2.387 \%$ and $80.62 \pm 7.277 \%$, respectively) in comparison with the control group $(46.79 \pm 2.404 \%)$. The level of p16 protein was decreased at $20 \mu \mathrm{g} / \mathrm{ml}(76.63 \pm 2.349 \%)$ and then increased at $30 \mu \mathrm{g} / \mathrm{ml}(81.25 \pm 6.263 \%)$ but the expression was lower than that of control $(90.00 \pm$ $0.805 \%)$. In conclusion, FB1 has a significant effect on TGF- $\beta 1$ and p16 protein expression at both doses (20 and $30 \mu \mathrm{g} / \mathrm{ml}$ ), and therefore, its role in cancer development is suggested.
\end{abstract}

Key words: Fumonisin B1, p16 protein, Transforming growth factor-beta (TGF- $\beta$ ).

\section{Introduction:}

Fungal toxins are toxic compounds with low molecular weight, produced by a few species of fungi in the field during the period of harvest (1). A broad spectrum of Fusarium species causes diseases in plants and produces important mycotoxins like trichothecenes, zearalenone, and fumonisins, which are the major threats to animals and humans (2). These toxins can cross the epithelium of intestine causing a diverse effect in the immune system by impairing the function of macrophages, neutrophils, decrease the activity of lymphocyte, as well as the production of antibody (3). The host becomes susceptible to infection with microorganisms during exposure to Fusarium toxins (4), depending on host factors such as; age, dose, and exposure time to the toxin (5).

${ }^{\mathrm{T}}$ Tropical Biological Research Unit, College of Science, University of Baghdad, Iraq.

2 National Cancer Research Center, University of Baghdad, Iraq.

${ }^{3}$ College of Science, University of Al-Karkh, Baghdad, Iraq.

${ }^{*}$ Corresponding author:sinaiwaleed47@uobaghdad.edu.iq "ORCID ID: https://orcid.org/0000-0001-8359-4921
Fumonisin B1 (FB1) is one of these toxins, and its carcinogenic effects in human and laboratory animals have been suggested. It deactivates the enzyme ceramide synthase and increases the concentration of sphinganine (Sa) and sphingosine (So) in tissue (6). Therefore, FB1 toxicity affects mainly the liver organ, which is characterized by apoptotic, necrosis, and regeneration (7). A recent study has found that FB1 can cause changes in the tissues of liver, lung, and kidney such as apoptosis and necrosis, leading to infiltration of inflammatory cells which were observed in these organs (8). Due to these histopathological changes, FB1 can be responsible for several diseases in human and animal including hepatotoxicity, nephrotoxicity, and neurotoxicity (9). Transforming growth factor-beta (TGF- $\beta$ ) is a cytokine that plays a serious role in the regulation of different cellular processes, and also important for homeostasis of tissues and organs (10). In contrast, p16 protein acts as a negative regulator to cell cycle progression (11).

Recent studies recorded that TGF- $\beta 1$ and p16 protein serves as biomarkers for malignant progression $(12,13)$, and since the contamination of 
human diet with mycotoxin is still a serious problem, so this study was planned to determine the effect of single exposure to FB1 on male mice at two doses; 20 and $30 \mu \mathrm{g} / \mathrm{ml}$, on immunohistochemical (IHC) expression of TGF- $\beta 1$ and p16 in liver cells.

\section{Material and Methods: \\ Preparation of FB1 solution}

The stock solution was prepared by dissolving $5 \mathrm{mg}$ of FB1 (Enzo life Science) in $5 \mathrm{ml}$ of acetonitrile: water and from this stock solution the doses were prepared.

\section{Estimation of TGF- $\beta 1$ and p16 protein by IHC}

Three groups of Swiss albino male mice (each of six animals) were treated with two single oral doses of FB1 $(20 \mu \mathrm{g} / \mathrm{ml}$ and $30 \mu \mathrm{g} / \mathrm{ml})$ as previously described (8). The first group was given normal saline, while groups 2 and 3 were administrated with the second and third doses of FB1, respectively and the animals were scarified after two weeks of the oral management. Liver samples of sacrificed animals were fixed in 10\% formalin and histological preparations were performed. The paraffin blocks of mice liver were used for immunohistochemistry technique (IHC) using anti-TGF- $\beta 1$ and anti-p16 antibodies. IHC was carried out according to manufacturer instructions of Cambridge Science Company. The TGF- $\beta 1$ and p16 protein expression were measured by enumerating positive cells with brown cytoplasmic staining (14).

\section{Statistical Analysis}

The results were given as mean \pm standard deviation (SD, $\mathrm{N}=6$ ). Significant differences between means were assessed by ANOVA (analysis of variance) followed by LSD (least significant difference). A probability $(p)$ value $\leq 0.05$ was considered significant. The statistical package SPSS version 16.0 was used to carry out these analyses.

\section{Results and Discussion:}

Due to little information about the effect of FB1 on some liver biomarker, this study was conducted by using IHC technique to study the effect of single dose of FB1on mice that were treated with 20 and $30 \mu \mathrm{g} / \mathrm{ml}$ via orally gavage route on the expression of TGF- $\beta 1$ and $\mathrm{p} 16$ protein in liver tissue. The results showed that exposure to FB1 caused significant elevation of TGF- $\beta 1$ in both doses $(76.74 \pm 2.387 \%$ and $80.62 \pm 7.277 \%$, respectively) in comparison with the control group $(46.79 \pm 2.404 \%)$ (Figs. 1 and 2). The level of p16 protein was decreased at $20 \mu \mathrm{g} / \mathrm{ml}(76.63 \pm 2.349 \%)$ and then increased at $30 \mu \mathrm{g} / \mathrm{ml}(81.25 \pm 6.263 \%)$ but the expression was lower than that of control $(90.00 \pm 0.805 \%)$ (Figs. 1 and 2). The results revealed a significant difference in the expression of liver biomarker between treatment and control groups $(p \leq 0.05)$. A previous study demonstrated an increased expression of TGF- $\beta 1$ by hepatocytes and caused apoptosis and fibrosis as seen in FB1induced liver injury and engaged in the tumorpromoting effects of $\mathrm{FB} 1(15,16)$.

Further research reported that FB1 induced organ lesions in some animal, which were characterized by apoptosis, necrosis, and proliferation, and due to this an imbalance between cell loss and replacement develops, causing good conditions for carcinogenesis $(5,17)$.

Another study suggested that the level of the p16 marker was not a significant sign to predict for oral squamous cell carcinoma samples (12). Further study found that p16 protein is a key player in preventing tumorigenesis, while, suppression of p16 and p53 proteins was the causes of human tumors (18).

\section{Conclusion:}

FB1 has a significant effect on TGF- $\beta 1$ and p16 protein expression at both doses (20 and 30 $\mu \mathrm{g} / \mathrm{ml})$, and therefore, its role in cancer development is suggested.

\section{Acknowledgments:}

The author would acknowledge all staff members of Tropical Biological Research Unit / College of Science and National Cancer Research Center, University of Baghdad, for supporting us in this work.

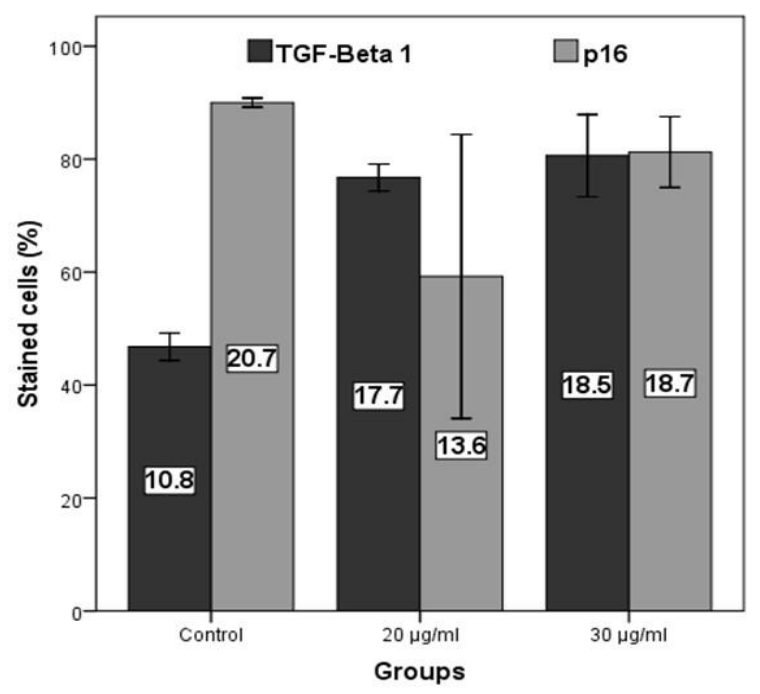

Figure 1. Level of TGF- $\beta 1$ and p16 expression in mice liver at three doses; Control (normal saline), $20 \& 30 \mu \mathrm{g} / \mathrm{ml}$ of FB1 toxin 


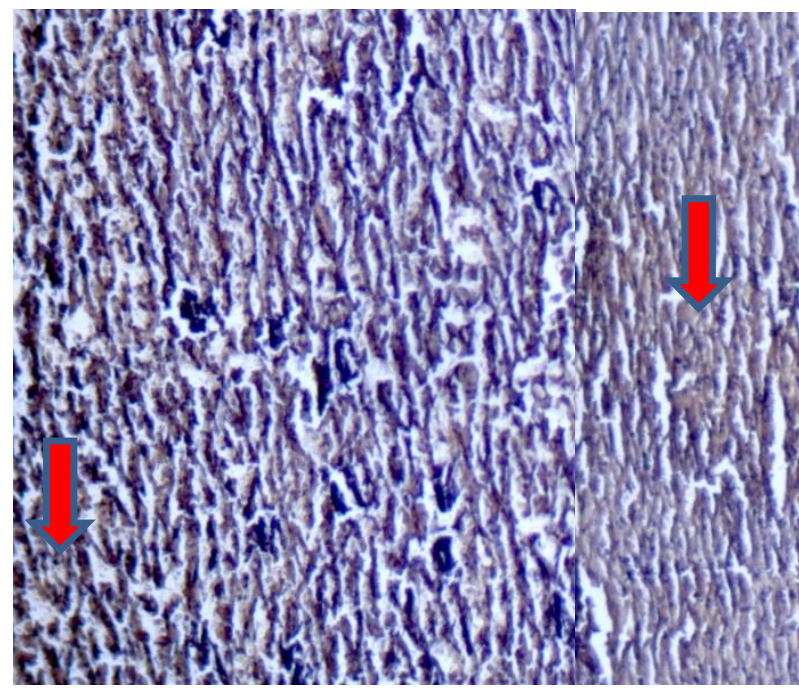

A

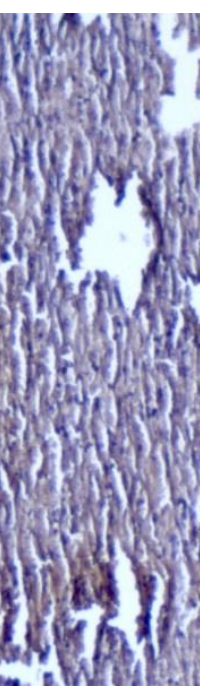

B

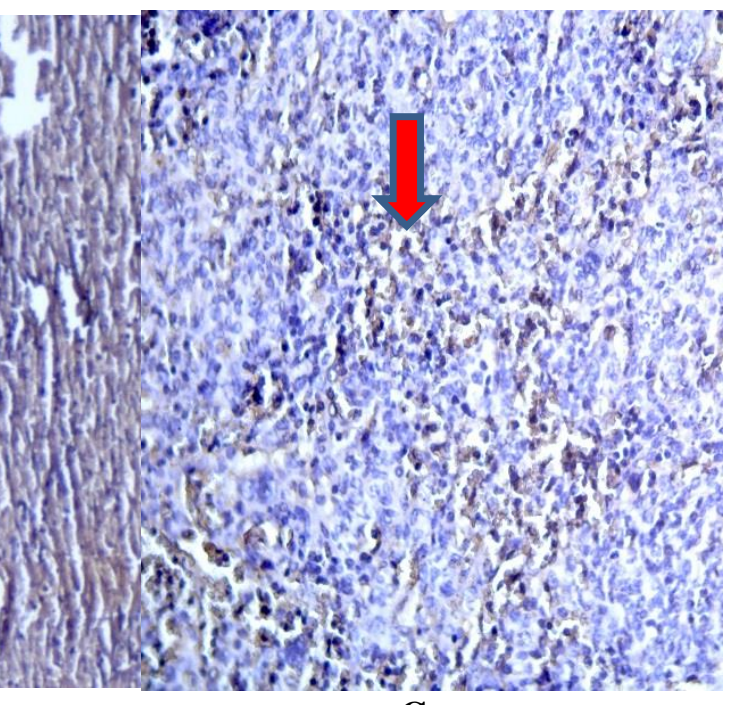

C

Figure 2. Distribution of TGF- $\beta 1$ in the liver of mice treated with the FB1 toxin: (A) $20 \mu \mathrm{g} / \mathrm{ml}$, (B) 30 $\mu \mathrm{g} / \mathrm{ml},(\mathrm{C})$ Control, (X200, Red arrow: Positive cells)

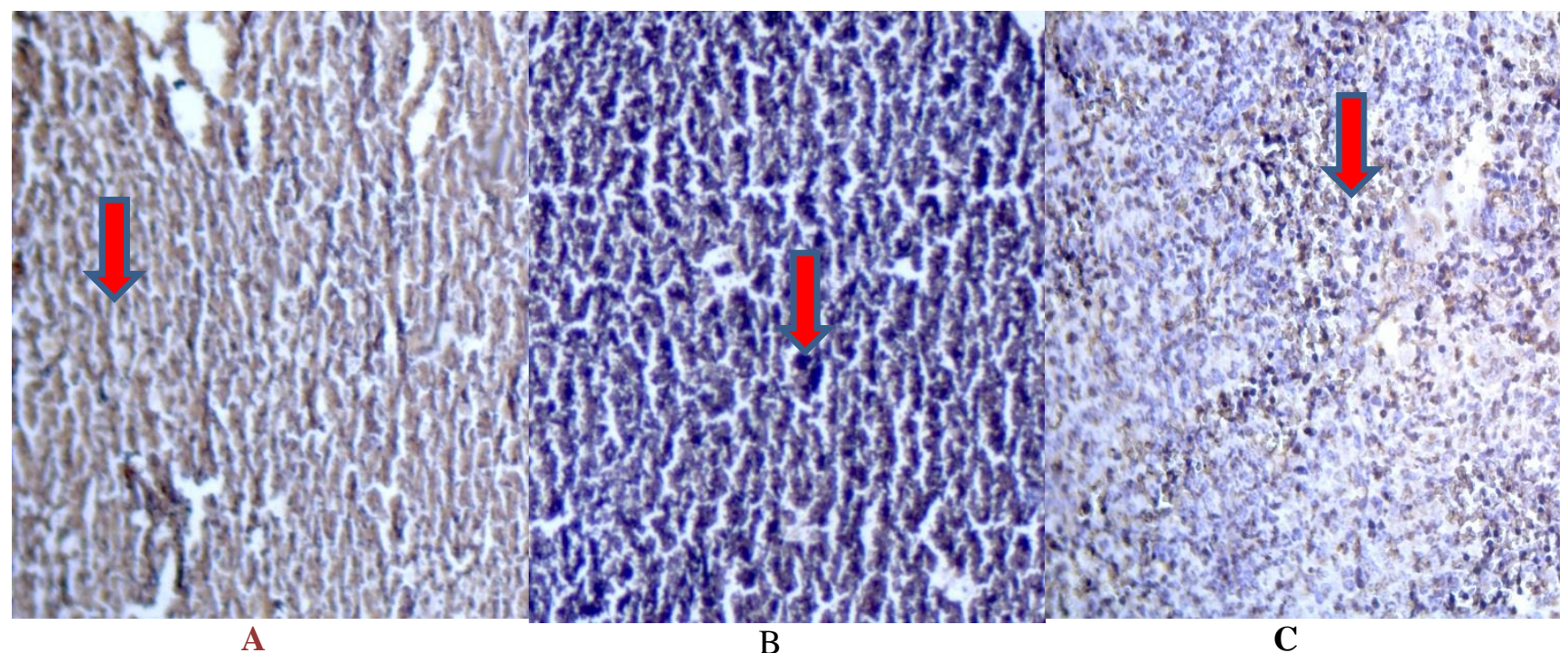

Figure 3. Distribution of p16 protein in the liver of mice treated with the FB1 toxin: (A) $20 \mu \mathrm{g} / \mathrm{ml}$, (B) $30 \mu \mathrm{g} / \mathrm{ml}$, (C) Control, (X200, Red arrow: Positive cells)

\section{Authors' declaration:}

- Conflicts of Interest: None.

- We hereby confirm that all the Figures and Tables in the manuscript are mine ours. Besides, the Figures and images, which are not mine ours, have been given the permission for republication attached with the manuscript.

- The author has signed an animal welfare statement.

- Ethical Clearance: The project was approved by the local ethical committee in University of Baghdad.

\section{References:}

1. Ismaiel A, Papenbrock J. Mycotoxins: Producing Fungi and Mechanisms of Phytotoxicity. Agriculture
[Internet]. 2015;5(3):492-537. Available from: http://www.mdpi.com/2077-0472/5/3/492/

2. Shi W, Tan Y, Wang S, Gardiner DM, De Saeger S, Liao Y, et al. Mycotoxigenic potentials of Fusarium species in various culture matrices revealed by mycotoxin profiling. Toxins (Basel). 2017;9(1).

3. Burel C, Tanguy M, Guerre P, Boilletot E, Cariolet R, Queguiner M, et al. Effect of Low Dose of Fumonisins on Pig Health: Immune Status, Intestinal Microbiota and Sensitivity to Salmonella. Toxins (Basel). 2013;5(4):841-64.

4. Antonissen G, Martel A, Pasmans F, Ducatelle R, Verbrugghe E, Vandenbroucke V, et al. The impact of Fusarium Mycotoxins on human and animal host susceptibility to infectious diseases. Toxins (Basel). 2014;6(2):430-52.

5. Basso K, Gomes F, Bracarense APL. Deoxynivanelol and fumonisin, alone or in combination, induce changes on intestinal junction complexes and in E- 
cadherin expression. Toxins (Basel). 2013;5(12):2341-52.

6. Voss KA, Riley RT. Fumonisin Toxicity and Mechanism of Action: Overview and Current Perspectives. Food Saf [Internet]. 2013;1(1):2013006-2013006. Available from: http://jlc.jst.go.jp/DN/JST.JSTAGE/foodsafetyfscj/20 13006?lang=en $\&$ from $=$ CrossRef $\&$ type $=$ abstract

7. Szabó A, Szabó-Fodor J, Kachlek M, Mézes M, Balogh K, Glávits R, et al. Dose and Exposure TimeDependent Renal and Hepatic Effects of Intraperitoneally Administered Fumonisin $\mathrm{B}_{1}$ in Rats. Toxins (Basel). 2018;10(11).

8. Mohammed SW, Habib KA, Al-Obaidie SR, Nayyef HJ, Khalaf N. Determination of the Toxicity of Fumonisin B1 on Male Albino Mice. Iraqi J Sci. 2017;58(1A):4-12.

9. Zain ME. Impact of mycotoxins on humans and animals. J Saudi Chem Soc [Internet]. 2011 [cited 2018 Oct 27];15:129-44. Available from: www.ksu.edu.sawww.sciencedirect.com

10. Fabregat I, Moreno-Caceres J, Sanchez A, Dooley S, Dewidar B, Giannelli G, et al. TGF-beta signalling and liver disease. FEBS J. 2016 Jun;283(12):221932.

11. Lu Y, Ma W, Li Z, Lu J, Wang X. The interplay between p16 serine phosphorylation and arginine methylation determines its function in modulating cellular apoptosis and senescence. Sci Rep [Internet]. 2017;7(December 2016):1-10. Available from: http://dx.doi.org/10.1038/srep41390

12. Salehinejad J , Sharifi N , Amirchaghmaghi M , Ghazi N , Shakeri MT GA. Immunohistochemical expression of p16 protein in oral squamous cell carcinoma and lichen planus . Ann Diagn Pathol 2014. 2014;18(4):24850170.

13. Salehinejad J, Sharifi N, Amirchaghmaghi M, Ghazi N, Shakeri MT, Ghazi A. Immunohistochemical expression of p16 protein in oral squamous cell carcinoma and lichen planus. Ann Diagn Pathol. 2014;18(4):210-3.

14. Lemmer ER, de la Motte Hall P, Omori N, Omori M, Shephard EG, Gelderblom WC, et al. Histopathology and gene expression changes in rat liver during feeding of fumonisin B1, a carcinogenic mycotoxin produced by Fusarium moniliforme. Carcinogenesis. 1999;20(5):817-24.

15. Merrill AH, Sullards MC, Wang E, Voss KA, Riley RT. Sphingolipid metabolism: Roles in signal transduction and disruption by fumonisins. Environ Health Perspect. 2001;109(SUPPL. 2):283-9.

16. Hani Rayess, Marilene B. Wang and ESS. Cellular senescence and tumor suppressor gene p16. Int J Cancer. 2012;130(8):1715-25. 17. Merrill AH, Sullards MC, Wang E, Voss KA, Riley RT. Sphingolipid metabolism: Roles in signal transduction and disruption by fumonisins. Environmental Health Perspectives 2001;109(SUPPL. 2): 283-289.

17. Merrill AH, Sullards MC, Wang E, Voss KA, Riley RT. Sphingolipid metabolism: Roles in signal transduction and disruption by fumonisins. Environmental Health Perspectives 2001;109(SUPPL. 2): 283-289.

18. Hani Rayess, Marilene B. Wang and ESS. Cellular senescence and tumor suppressor gene p16. Int J Cancer. 2012;130(8): 1715-1725. 
التعبير المناعي النسيجي للبروتين ب16 و عامل النمو المحول بيتا1 في كبد الفئران المعرضة للسم فيومنسين 1 ب

ميساء كاظم المالكي 1 الهُى فخري خلف1

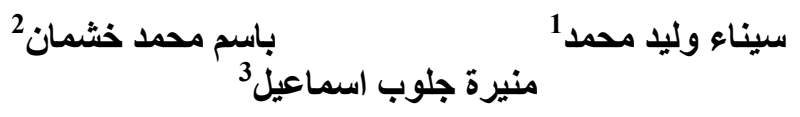

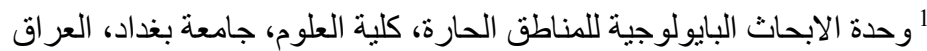

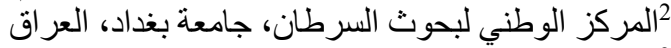

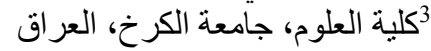

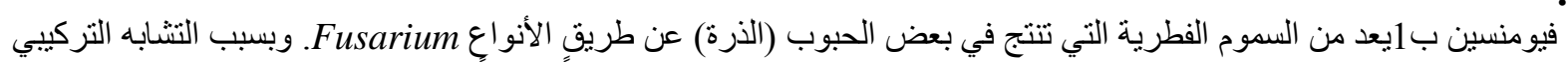

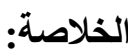

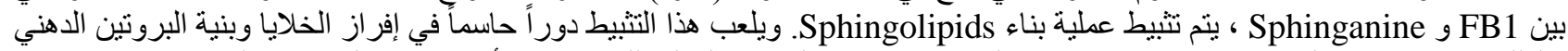

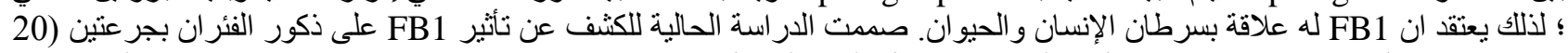

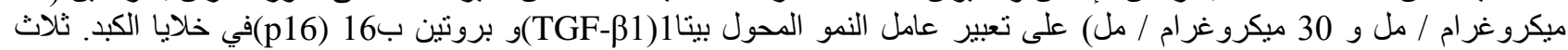

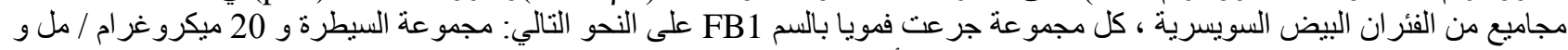

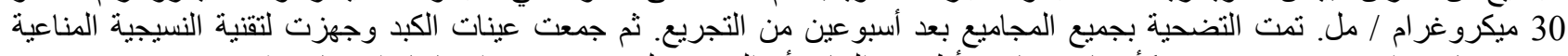

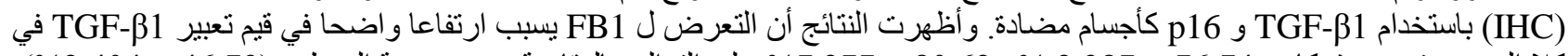

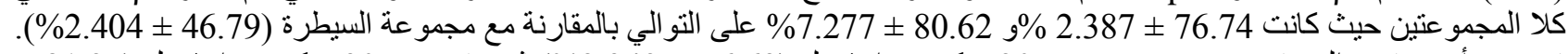

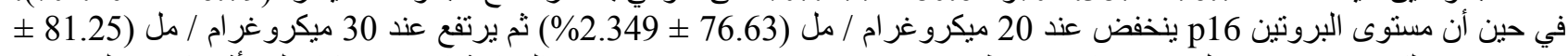

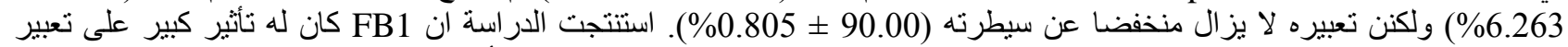

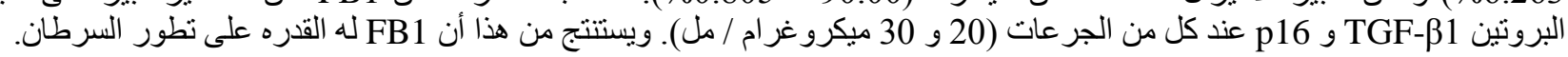

الكلمات المفتاحية: فيومنسين ب1، بروتين ب16، عامل النمو المحول بيتا 